\title{
Lower temperature influences Cauliflower mosaic virus systemic infection
}

\author{
Roberto Alers-Velazquez ${ }^{1} \cdot$ Sushant Khandekar ${ }^{1} \cdot$ Clare Muller $^{1} \cdot$ Jennifer Boldt ${ }^{2} \cdot$ Scott Leisner $^{1}$
}

Received: 26 February 2021 / Accepted: 18 March 2021 / Published online: 28 March 2021

(c) The Author(s) 2021

\begin{abstract}
Lower temperatures delayed development of systemic symptoms by Cauliflower mosaic virus (CaMV) in two different plant hosts. However, lower temperature exposure increased CaMV nucleic acid levels in leaves of systemically-infected turnips. Furthermore, lower temperature altered the formation of aggregates formed by the CaMV major inclusion body (IB) protein, P6. Finally, lower temperature altered the architecture of the actin cytoskeleton. These data may suggest that lower temperatures alter the actin cytoskeleton, facilitating the formation of larger IBs that hold on to their internal virions more strongly than small ones, impairing virus particle release and causing a delay in systemic infection.
\end{abstract}

Keywords QPCR · CaMV · P6 · Inclusion bodies · Talin

Plant viral infections are influenced by a variety of environmental factors (Kassanis 1957; Liu et al. 2009). However, many questions remain regarding the relationship between temperature, virus propagation, and host-responses (Honjo et al. 2020). During the course of our work, interesting effects of temperature on Cauliflower mosaic virus (CaMV) infection were serendipitously discovered.

Cauliflower mosaic virus (CaMV) is a plant pararetrovirus that infects mainly cruciferous plants (Haas et al. 2002; Hull 2002; Hull and Covey 1985; Schoelz and Leisner 2017). Once introduced into plant cells by wounding or via aphids, CaMV virus particles are targeted to the nucleus, where the genomic DNA enters, is assembled into a minichromosome by binding to host histones, and is transcribed to synthesize two RNAs (19S and 35S) by host RNA polymerase II. The 19S RNA encodes the gene VI product, P6. The 35S RNA plays a dual role, serving as the polycistronic transcript for all the viral proteins along with acting as a template for reverse transcription to reconstitute the viral

Scott Leisner

Scott.Leisner@utoledo.edu

1 Department of Biological Sciences, University of Toledo, 2801 West Bancroft Street, Mail Stop 601, Toledo, OH 43606, USA

2 Application Technology Research Unit, USDA-Agricultural Research Service, 2801 West Bancroft Street, Mail Stop 604, Toledo, OH 43606, USA genome. CaMV genomic DNA, protein synthesis and virion assembly occur in cytoplasmic structures mainly composed of P6, called inclusion bodies (IBs) (Hohn 2013; Leisner and Schoelz 2018; Schoelz and Leisner 2017). IBs move along actin filaments (Harries et al. 2009) and this movement may be required for formation and fusion of smaller aggregates into larger ones (Alers-Velazquez et al. 2021).

Because of space limitations that developed in a previous study, CM1841-infected Chinese violet cress (Orychophragmus violaceus) was propagated in two greenhouses that ended up with different mean temperatures. Unexpectedly, plants grown in the lower temperature $\left(18{ }^{\circ} \mathrm{C}\right)$ greenhouse developed systemic symptoms more slowly compared to plants propagated at a higher temperature $\left(22^{\circ} \mathrm{C}\right)$, which caused us to investigate further.

To ensure temperature was the deciding factor, Chinese violet cress was grown in moist soilless medium (Lambert, Quebec, Canada) in $10 \mathrm{~cm}$ square pots supplemented with $2.15 \mathrm{~g}$ per pot of Osmocote ${ }^{\circledR}$ Smart-Release ${ }^{\circledR}$ plant food 14-14-14 (Scotts Company, Marysville, OH, USA). Plants were then maintained in a growth chamber $\left(25^{\circ} \mathrm{C}\right.$ air temperature, $45 \%$ humidity $)$ under a $16 \mathrm{~h}$ light $\left(130 \mu \mathrm{mol} \mathrm{m} \mathrm{m}^{-2} \mathrm{~s}^{-1}\right.$ photosynthetic photon flux density $(P P F D)$ ) and $8 \mathrm{~h}$ dark cycle. When the plants had developed 4-5 true leaves (usually about 4 weeks after sowing under the above-described environmental conditions), Chinese violet cress was then acclimated for 10 days at $18{ }^{\circ} \mathrm{C}$ or $22^{\circ} \mathrm{C}$ (no change to other environmental conditions). Six plants per temperature were 
inoculated with cell sap extract from turnips (Brassica rapa) systemically-infected with CaMV isolate CM1841 (Gardner et al. 1981) as described in Leisner et al. (1992). Symptom formation was monitored daily. The time elapsed until the first leaf on each plant to showed complete systemic symptom coverage was recorded as the time for systemic symptom formation. Infected plants grown at $22^{\circ} \mathrm{C}$ began to show symptoms after $\sim 36$ days post-inoculation (DPI) (Fig. 1a), while plants grown at $18{ }^{\circ} \mathrm{C}$ began exhibiting systemic symptoms $\sim 25$ days later.

To determine if this temperature-dependent delay in CaMV systemic symptom formation was unique to Chinese violet cress, turnips (cv. Just Right) were inoculated with CM1841 and maintained in growth chambers at $18{ }^{\circ} \mathrm{C}$ and $22{ }^{\circ} \mathrm{C}$ under the conditions described above. As hypothesized, a similar result was observed (Fig. 1b). All turnips inoculated with CaMV grown at $22{ }^{\circ} \mathrm{C}$ displayed systemic symptoms 10-13 DPI, while infected plants grown at $18^{\circ} \mathrm{C}$ developed systemic symptoms 17-23 DPI. However, symptom severity appeared similar at both temperatures. These data are similar to findings reported by Pound and Walker (1945a, b) who reported that CaMV infection was delayed by lower temperatures in Brassica oleracea (cabbage). Yamaoka et al. (1982) reported that turnips inoculated with CaMV also showed a delay in systemic symptoms at lower temperature $\left(20^{\circ} \mathrm{C}\right)$ compared to a higher temperature $\left(30^{\circ} \mathrm{C}\right)$. Brusse $(1965)$ also showed a delay of CaMV systemic infection in turnips grown at $15{ }^{\circ} \mathrm{C}$ compared to $21{ }^{\circ} \mathrm{C}$. Therefore, the observation that lower temperatures delay systemic symptom formation appears to be a common property of CaMV infection.

One possible explanation for the delay in symptom expression at the lower temperature is that the reduced temperature affected plant biochemical processes, such as altering plant photosynthetic capacity (Athanasiou et al.
2010), which could influence virus infection. Photosynthetic rate and chlorophyll fluorescence parameters were measured on both turnips (a CaMV host) and Nicotiana benthamiana (which is not a host), to examine the effects of temperature on host physiology and permit comparison of the responses between the two plant species. Measurements were made on non-infected plants to examine the effect of temperature alone. If both species were impacted similarly by temperature, then their physiology likely would be behaving in a similar way. $N$. benthamiana was selected because it is an excellent model plant for confocal microscopy studies that are not possible in a CaMV host plant.

Chlorophyll fluorescence measurements of plants acclimated at $18{ }^{\circ} \mathrm{C}$ or $22{ }^{\circ} \mathrm{C}$ for 1 week were measured using a LI-6800 portable photosynthesis system (LI-COR Biosciences, Lincoln, NE, USA). Recently mature (fullyexpanded, non-shaded) leaves of five (turnip) or four ( $N$. benthamiana) randomly selected plants per temperature were measured. Leaf chamber conditions matched the respective growth chambers: $18{ }^{\circ} \mathrm{C}$ or $22{ }^{\circ} \mathrm{C}$ air temperature, $400 \mathrm{ppm}$ carbon dioxide $\left(\mathrm{CO}_{2}\right)$ concentration and 150 or $0 \mu \mathrm{mol} \mathrm{m} \mathrm{m}^{-2} \mathrm{~s}^{-1}$ PPFD (for light and dark-acclimated measurements, respectively; was provided by a 90:10 ratio of red:blue light-emitting diodes (LEDs)). Initial measurements $\left(F_{m}{ }^{\prime}, F_{s}\right)$ were collected on light-acclimated plants, starting at least $1 \mathrm{~h}$ after growth chamber lights turned on. Then chamber lights were turned off for $1 \mathrm{~h}$ to allow plants to dark-acclimate, after which $\mathrm{F}_{\mathrm{o}}$ and $\mathrm{F}_{\mathrm{m}}$ were recorded. The ratio of variable $\left(\mathrm{F}_{\mathrm{v}} ; \mathrm{F}_{\mathrm{m}}-\mathrm{F}_{\mathrm{o}}\right)$ to maximum fluorescence $\left(\mathrm{F}_{\mathrm{v}} / \mathrm{F}_{\mathrm{m}}\right.$; fraction of absorbed photons utilized for photochemistry by photosystem II (PSII) in a dark-acclimated leaf), effective quantum yield $\left(\Phi_{\mathrm{PSII}} ;\left(\mathrm{F}_{\mathrm{m}}{ }^{\prime}-\mathrm{F}_{\mathrm{s}}\right) / \mathrm{F}_{\mathrm{m}}{ }^{\prime}\right.$; fraction of absorbed photons utilized by PSII for photochemistry in a light-acclimated leaf) and electron transport rate a

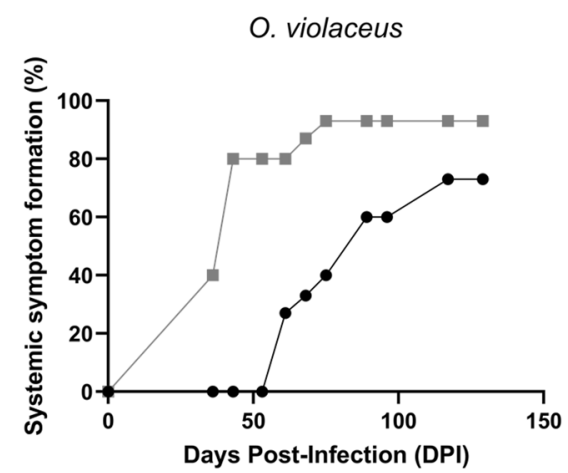

Fig. 1 Temperature effects on CaMV systemic symptom formation. Systemic symptom formation in CaMV-infected a Chinese violet cress and b turnips, grown at $18{ }^{\circ} \mathrm{C}$ and $22{ }^{\circ} \mathrm{C}$. Gray squares indi- b

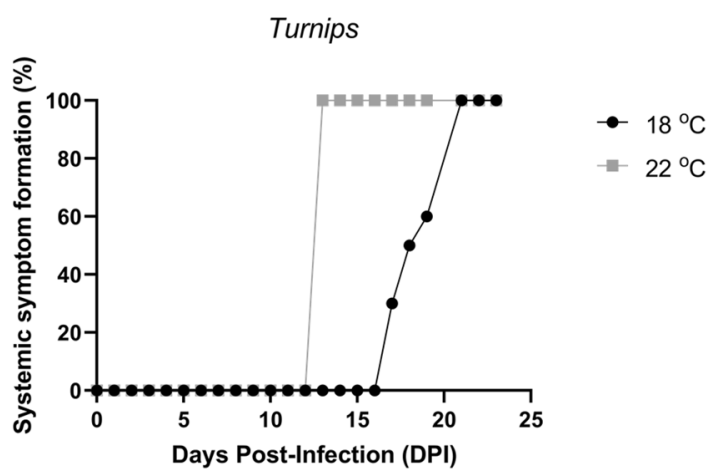

cate plants grown at $22{ }^{\circ} \mathrm{C}$; black circles, $18{ }^{\circ} \mathrm{C}$. $\mathrm{x}$-axis indicates days post-inoculation and y-axis indicates percentage of plants (out of 10) displaying full systemic symptoms on their first leaf 
$\left(\mathrm{ETR} ; \Phi_{\mathrm{PSII}} \times 0.5 \times\right.$ absorbed irradiance) were calculated as described by Torres et al. (2014).

Chlorophyll fluorescence measurements (Table 1) in both turnip and $N$. benthamiana showed no significant differences between the two temperatures for ETR or $\Phi_{\text {PSII }}$. While a slight significant increase in $\mathrm{F}_{\mathrm{v}} / \mathrm{F}_{\mathrm{m}}$ was observed in turnip (but not $N$. benthamiana) at the lower temperature, all values were still in the range (0.7-0.8) typical of non-stressed plants (Baker 2008; Ritchie et al. 2006), which likely means this difference is not biologically relevant. This slight increase in $\mathrm{F}_{\mathrm{v}} / \mathrm{F}_{\mathrm{m}}$ at $18{ }^{\circ} \mathrm{C}$ could be due to the observation that turnips prefer a cooler temperature range than $N$. benthamiana (Brickell 1994; Young-Matthews 2012). Together, these data suggest that the temperature difference is not causing major changes to photosynthetic function for either species.

To examine the effects of temperature on virus components, viral DNA and 35S DNA levels were measured. Since symptoms appeared later in plants grown at the lower temperature, we believed it was important to measure viral macromolecule levels in systemically-infected leaves at the same stage of infection. Replication intermediates and transcript levels can change with stage of infection (Covey and Turner 1991). As illustrated in Fig. 1a, b, the infection process was not temporally synchronized. Therefore, the first leaf to show systemic symptoms over the entire leaf surface was used as our landmark to correlate infection at the two temperatures. Leaves were harvested as soon as they exhibited systemic symptoms.

The same amount of leaf tissue $(\sim 100 \mathrm{mg})$ from each infected plant within a temperature treatment was pooled into one sample. Uncapsidated and total viral DNA was isolated as described in Lutz et al. (2015). Total RNA was isolated from pooled tissues using the RNeasy Plant Mini Kit (Qiagen, Germantown, MD, USA) with on-column DNase digestion according to the manufacturer's specifications.

The effect of temperature on viral transcript and genome levels was investigated by quantitative PCR. Viral RNA levels were measured by one-step reverse transcriptase-quantitative polymerase chain reaction (RTqPCR) using the iTaq ${ }^{\circledR}$ Universal SYBR ${ }^{\circledR}$ Green One-Step RT-qPCR kit (Bio-Rad, Hercules, CA, USA) as described by the manufacturer's specifications. Viral DNA was quantified in the same manner as viral RNA described above, only the reverse transcriptase step was omitted and just qPCR was performed. Primers 5'-AGCGGTCAAAATATTGCTTA-3' and 5'-AACTTACCGTATGCTAGATTACCT-3' (Love et al. 2005), that amplify a $141 \mathrm{bp}$ fragment of gene I spanning nucleotides 753-893 were used for quantification of viral DNA. These primers amplify the 35S RNA but not the 19S RNA (that mainly spans gene VI, reviewed in Schoelz and Leisner 2017 and references therein) nor the short stop RNA (Sanfaçon and Wieczorek 1992). Viral RNA and DNA measurements were normalized against $18 \mathrm{~S}$ ribosomal RNA or DNA levels, respectively, using primers 5'-CGTGATCGA TGAATGCTACC-3' and 5'-GGGGTTTGTTGCACGTAT TA-3' (Love et al. 2005) that amplify a 199 bp fragment. Analysis of nucleic acid levels was performed as described in Lutz et al. (2015).

RT-qPCR data revealed that 35S RNA levels for plants grown at $18{ }^{\circ} \mathrm{C}$ were significantly higher than at $22{ }^{\circ} \mathrm{C}$ (Fig. 2a). Because CaMV is a pararetrovirus (Haas et al. 2002; Schoelz and Leisner 2017), we might expect viral DNA levels to match those of viral RNA. Indeed, total viral DNA levels were also significantly higher in leaves of CM1841-infected plants grown at $18{ }^{\circ} \mathrm{C}$ compared to $22{ }^{\circ} \mathrm{C}$ (Fig. 2c). Moreover, quantification of viral DNA when infected tissue was not treated with Proteinase $\mathrm{K}$ (which examines non-encapsidated viral DNA) showed a similar effect (Fig. 2b). This suggests the higher viral DNA levels are not strictly from packaged virions. Even though we measured viral DNA levels, our data agree with those reported by Pound and Walker (1945a, b) who, based on plant inoculation assays, showed that the number of infectious units was higher in the lower temperature-exposed, CaMV-infected plants.
Table 1 Photosynthetic parameters for Nicotiana benthamiana and turnips at two temperatures

\begin{tabular}{lccccc}
\hline Measurement & Mean at $18{ }^{\circ} \mathrm{C}$ & Mean at $22^{\circ} \mathrm{C}$ & $\mathrm{df}$ & $\mathrm{t}$ & $\mathrm{p}$-value \\
\hline N. benthamiana & & & & & \\
$\mathrm{F}_{\mathrm{v}} / \mathrm{F}_{\mathrm{m}}$ & $0.77 \pm 0.018$ & $0.79 \pm 0.014$ & 6 & -1.472 & 0.192 \\
$\Phi_{\mathrm{PSII}}\left(\mu \mathrm{mol} \mathrm{m}{ }^{-2} \mathrm{~s}^{-1}\right)$ & $0.52 \pm 0.038$ & $0.56 \pm 0.044$ & 6 & -1.462 & 0.194 \\
ETR $\left(\mu \mathrm{mol} \mathrm{m}{ }^{-2} \mathrm{~s}^{-1}\right)$ & $35.62 \pm 3.00$ & $38.52 \pm 2.61$ & 6 & -1.455 & 0.196 \\
Turnips & & & & & \\
$\mathrm{F}_{\mathrm{v}} / \mathrm{F}_{\mathrm{m}}$ & $0.81 \pm 0.004$ & $0.80 \pm 0.008$ & 8 & 3.51 & 0.008 \\
$\Phi_{\mathrm{PSII}}\left(\mu \mathrm{mol} \mathrm{m} \mathrm{m}^{-1}\right)$ & $0.67 \pm 0.016$ & $0.65 \pm 0.023$ & 8 & 0.963 & 0.364 \\
ETR $\left(\mu \mathrm{mol} \mathrm{m}^{-2} \mathrm{~s}^{-1}\right)$ & $45.63 \pm 1.11$ & $44.80 \pm 1.60$ & 8 & 0.948 & 0.371 \\
\hline
\end{tabular}

Plants were acclimated to $18{ }^{\circ} \mathrm{C}$ or $22{ }^{\circ} \mathrm{C}$ for 10 days and chlorophyll fluorescence measurements were determined using a LI-6800. Four ( $N$. benthamiana) or five (turnip) plants were measured for each species at each temperature. Note, all the parameters showed no significant difference between the two temperatures except for $\mathrm{F}_{\mathrm{v}} / \mathrm{F}_{\mathrm{m}}$ for turnip 


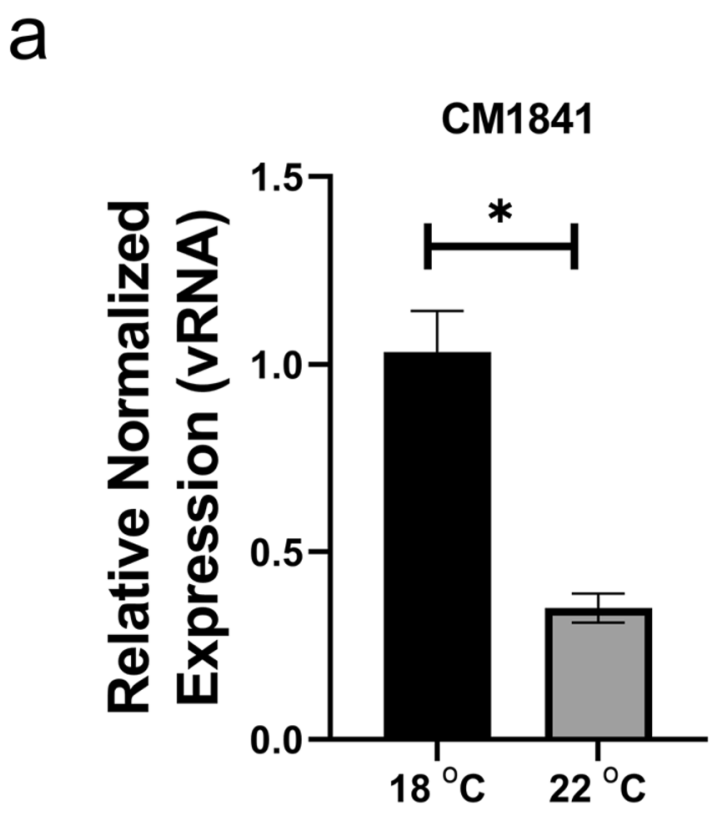

b

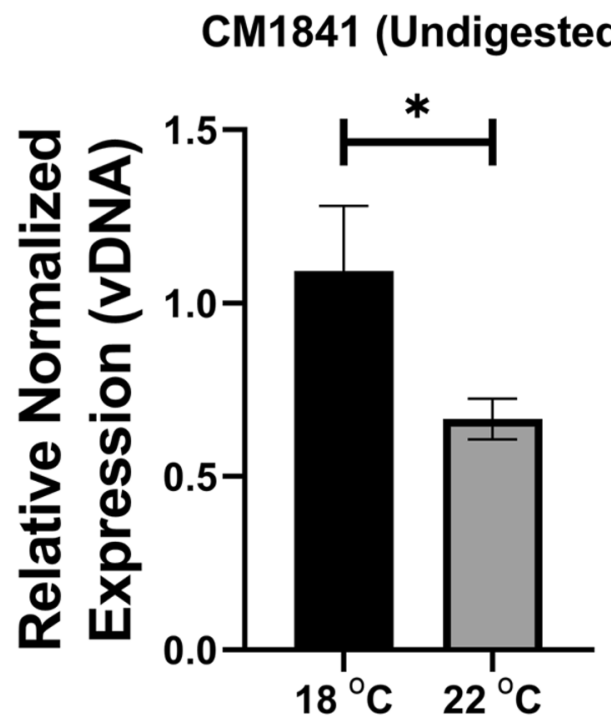

C

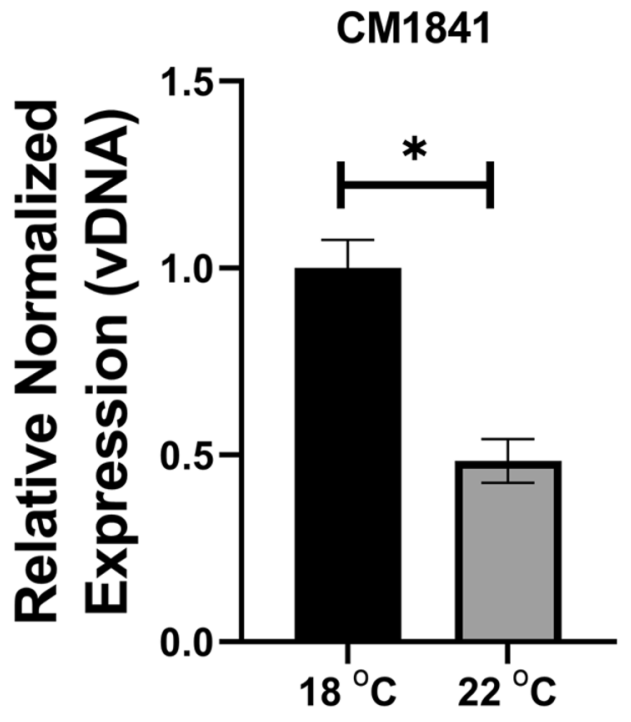

Fig. 2 CaMV viral genome quantification. CaMV-infected tissue from turnips was harvested for nucleic acid isolation and qPCR. a Viral RNA quantification of systemically-infected plants grown at $18{ }^{\circ} \mathrm{C}$ and $22{ }^{\circ} \mathrm{C}$. b Unencapsidated viral DNA from systemicallyinfected plants grown at $18{ }^{\circ} \mathrm{C}$ and $22{ }^{\circ} \mathrm{C}$ not treated with protein-

ase K. c. Total viral DNA from systemically-infected plants grown at $18{ }^{\circ} \mathrm{C}$ and $22{ }^{\circ} \mathrm{C}$, treated with proteinase K. Note, for all graphs, black bars represent macromolecules from plants grown at $18{ }^{\circ} \mathrm{C}$ and gray bars, $22^{\circ} \mathrm{C}$. Asterisks indicate a significant difference at $P<0.05$

The elevated viral nucleic acid levels at the lower temperature could be explained by the observation that lower temperatures can inhibit plant siRNA pathways (Szittya et al. 2003). If these pathways were restricted in our study, more CaMV 35S RNA would accumulate. Since CaMV is a pararetrovirus (Haas et al. 2002; Schoelz and Leisner

2017), increased 35S RNA levels could result in elevated DNA levels. In our case, we observed elevated levels of both $35 \mathrm{~S}$ transcripts along with encapsidated and unencapsidated viral intermediates at the lower temperature. Other reports (Covey and Turner 1991; Saunders et al. 1990) have shown that early in infection, the levels of the supercoiled 
minichromosome are relatively low, while the amounts of viral transcripts and replication intermediates are high. Late in infection, the situation is reversed. We are unclear which forms of unencapsidated DNA are present but we would predict, based on previous reports (Covey and Turner 1991; Saunders et al. 1990), that the ratio of the levels of supercoiled unencapsidated DNA to replication intermediates would be lower at $18{ }^{\circ} \mathrm{C}$ compared to $22^{\circ} \mathrm{C}$.

$\mathrm{CaMV}$ protein synthesis, genome replication, and virion assembly occurs in IBs (Schoelz and Leisner 2017). Because CaMV macromolecule levels were higher at $18{ }^{\circ} \mathrm{C}$ than at $22^{\circ} \mathrm{C}$, it was possible that IB formation was altered by temperature. Therefore, IB formation was investigated. P6 is the major IB protein that can form IBs visible by confocal microscopy when tagged with fluorescent proteins and expressed in $N$. benthamiana leaves (reviewed in Schoelz and Leisner 2017). Since $N$. benthamiana is not a host for CM1841, we only examined IB formation by P6 alone at the two temperatures, not in the context of a viral infection.

Plant expression constructs expressing full-length CM1841 P6 fused to GFP and Talin fused to DsRed were previously reported (Alers-Velazquez et al. 2021; Angel et al. 2013; Lutz et al. 2015). Constructs were agroinfiltrated into $N$. benthamiana leaves and confocal microscopy was performed as described in Alers-Velazquez et al. (2021). Images, movies, size distribution and IB velocity measurements were performed as described by Alers-Velazquez et al. (2021).

IBs formed in leaf cells of inoculated $N$. benthamiana at both temperatures (Fig. 3a, b). However, there appeared to

\section{a}

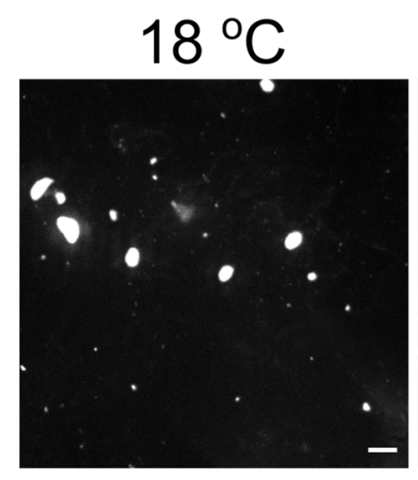

b

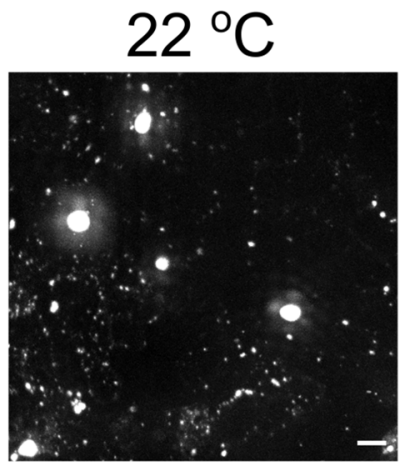

C

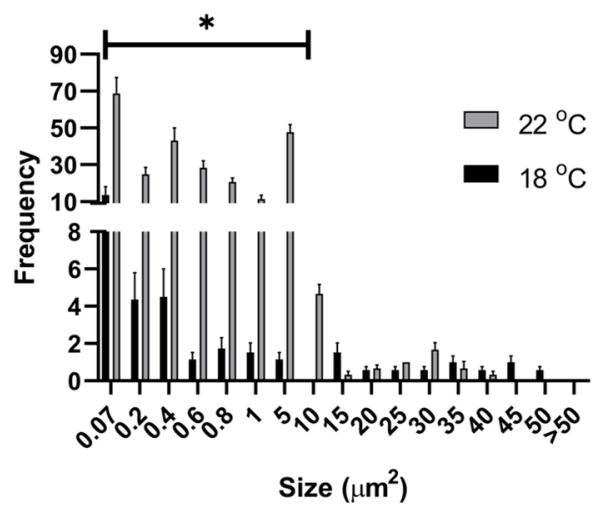

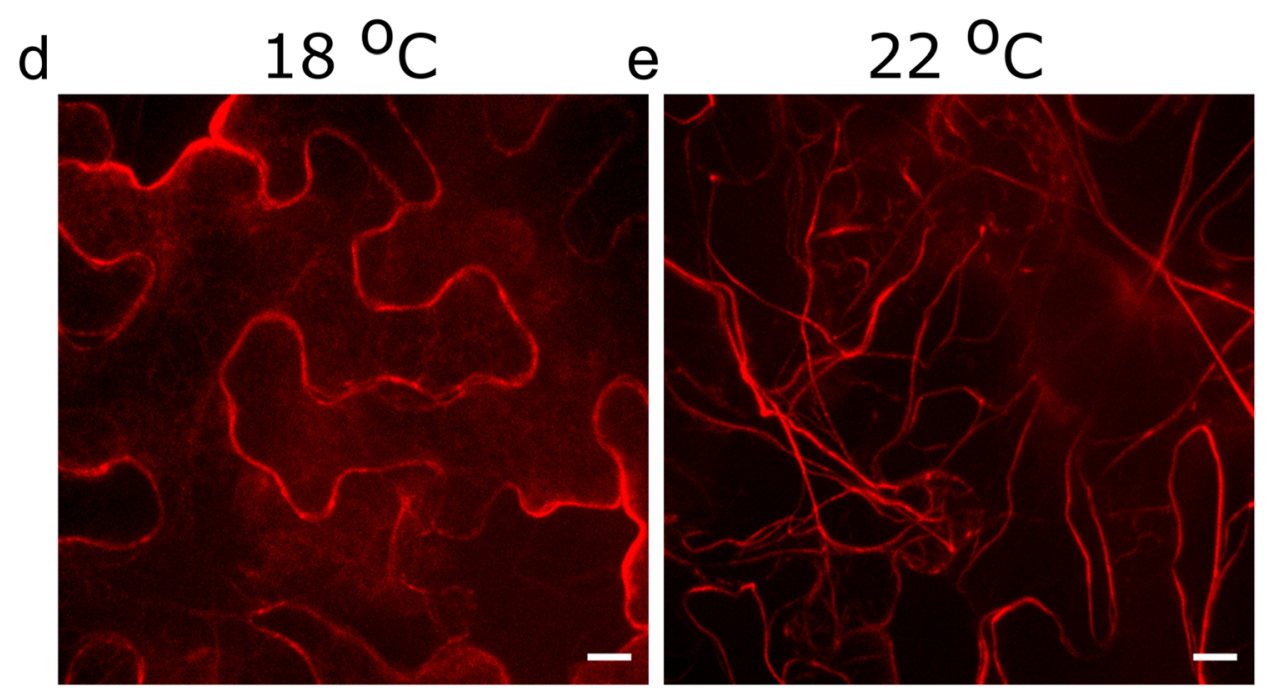

Fig. 3 Low temperature effects on inclusion body size distribution and actin framework. Confocal microscopy image analysis of Nicotiana benthamiana plants agroinfiltrated with a P6-GFP-expressing construct. Confocal images of inclusion bodies from plants grown at a $18{ }^{\circ} \mathrm{C}$ or b $22{ }^{\circ} \mathrm{C}$. Scale bar: $10 \mu \mathrm{m}$. c Inclusion body size distribution analysis between $18{ }^{\circ} \mathrm{C}$ (black bars) and $22^{\circ} \mathrm{C}$ (gray bars). Nico- tiana benthamiana plants grown at $\mathbf{d} 18{ }^{\circ} \mathrm{C}$ or $\mathbf{e} 22^{\circ} \mathrm{C}$ were agroinfiltrated with Talin-dsRed and analyzed by confocal microscopy. Scale bar: $10 \mu \mathrm{m}$. Size, $\mathrm{x}$-axis indicates IB area in square micrometers; Frequency, $y$-axis, the number of IBs. The IBs of specific size classes for $18{ }^{\circ} \mathrm{C}$ or $22{ }^{\circ} \mathrm{C}$ that were significantly different at $P<0.05$ are indicated with an asterisk. $n=3$ 
be fewer smaller $\left(\leq 10 \mu \mathrm{m}^{2}\right)$ and more larger IBs at $18{ }^{\circ} \mathrm{C}$ than at $22{ }^{\circ} \mathrm{C}$. Quantification of the IB size distribution (Fig. 3c) showed this was indeed the case. Additionally, the total number of IBs at $18{ }^{\circ} \mathrm{C}$ significantly decreased compared to $22{ }^{\circ} \mathrm{C}$ (Fig. S1a). Even though the number of IBs was lower at $18{ }^{\circ} \mathrm{C}$, this temperature seemed to significantly favor the formation of IBs $\geq 40 \mu \mathrm{m}^{2}$ (Fig. S1b). The difference in temperature did not significantly affect IB mobility (Fig. S2). Both temperatures showed a similar proportion of high to low-mobility IBs. These data suggest that the lower temperature facilitated the fusion of smaller IBs into larger ones, producing the altered size distribution. Alers-Velazquez et al. (2021) showed that large IBs exhibited properties similar to liquid-liquid phase separated compartments and appeared to have a 1,6-hexanediol-resistant, possibly gel-like core. Thus, large IBs may hold onto their virions more strongly than smaller ones do, which could account for the differences in the rate of infection under the two temperature conditions.

CaMV IBs are associated with and move along actin filaments (Angel et al. 2013) and lower temperatures alter the organization of the actin cytoskeleton in Arabidopsis thaliana (Fan et al. 2015). Thus, the difference in temperature in our studies could have affected the actin cytoskeletal network. When leaves of $N$. benthamiana plants grown at $22^{\circ} \mathrm{C}$ or $18{ }^{\circ} \mathrm{C}$ were infiltrated with Talin-DsRed (that binds actin filaments (Angel et al. 2013)), confocal microscopy did indeed show differences in actin cytoskeletal organization at the two temperatures. $N$. benthamiana leaf cells in plants grown at $22^{\circ} \mathrm{C}$ (Fig. 3e) showed a coarse network of well-defined actin cables running through the cytoplasm. However, cells from plants grown at $18{ }^{\circ} \mathrm{C}$ showed an altered organization of actin (Fig. 3d). It is possible that the altered actin cytoskeleton induced by low temperature concentrated IBs, facilitating fusion of small IBs into larger ones. These data may also explain the difference between our findings and those of Yamaoka et al. (1982). These authors reported that IB size was larger in infected plants propagated at $30^{\circ} \mathrm{C}$, compared to those grown at $20^{\circ} \mathrm{C}$. However, virus production was lower at $30^{\circ} \mathrm{C}$, possibly indicating that the pathosystem may be under stress. Thus, it may be that plants under stress exhibit an altered actin cytoskeleton. In future studies, it will be interesting to determine if the actin cytoskeletal architecture at $30{ }^{\circ} \mathrm{C}$ in our system resembles that at $18{ }^{\circ} \mathrm{C}$.

In summary we report that CaMV systemic infection is delayed by low temperature. In spite of this, infected plants grown at $18^{\circ} \mathrm{C}$ exhibited higher levels of viral 35S RNA and DNA, relative to $22{ }^{\circ} \mathrm{C}$. These higher levels of viral macromolecules were correlated with a larger IB size distribution, presumably due to a restructuring of the actin cytoskeleton caused by the lower temperature conditions. It is interesting to note that certain P6 mutant viruses that produce mainly small IBs also show a reduction in viral nucleic acid levels
(Lutz et al. 2015). So large IBs may be more efficient at synthesizing viral macromolecules than smaller ones. However, larger IBs may also hold onto their virions more effectively than smaller ones. This may impair release of virions from IBs and delay systemic infection. It is also possible that lower temperatures affect another aspect of virus infection such as restricting cell-to-cell or long-distance movement, delaying the development of systemic infections.

Supplementary Information The online version contains supplementary material available at https://doi.org/10.1007/s10327-021-01003-y.

Acknowledgements The authors thank Dr. Qian Chen (Department of Biological Sciences, University of Toledo) for assistance with confocal microscopy, Sarah Jacques (Department of Biological Sciences, University of Toledo) for her assistance with plant growth, and the University of Toledo Plant Science Research Center. The authors would also like to thank Dr. James Schoelz (Division of Plant Sciences, University of Missouri) for the gifts of the P19 and Talin-DsRed constructs. This work was supported in part by US Department of Agriculture-Agricultural Research Service Specific Cooperative Agreement (Grant number: 58-5082-6-012). Mention of trade names or commercial products in this publication is solely for the purpose of providing specific information and does not imply recommendation or endorsement by the University of Toledo or the U.S. Department of Agriculture. USDA is an equal opportunity provider and employer.

\section{Declarations}

Conflict of interest The authors declare that they have no conflict of interest.

Ethical approval This article does not contain any studies with human participants or animals performed by any of the authors.

Open Access This article is licensed under a Creative Commons Attribution 4.0 International License, which permits use, sharing, adaptation, distribution and reproduction in any medium or format, as long as you give appropriate credit to the original author(s) and the source, provide a link to the Creative Commons licence, and indicate if changes were made. The images or other third party material in this article are included in the article's Creative Commons licence, unless indicated otherwise in a credit line to the material. If material is not included in the article's Creative Commons licence and your intended use is not permitted by statutory regulation or exceeds the permitted use, you will need to obtain permission directly from the copyright holder. To view a copy of this licence, visit http://creativecommons.org/licenses/by/4.0/.

\section{References}

Alers-Velazquez R, Jacques S, Muller C, Boldt J, Schoelz J, Leisner S (2021) Cauliflower mosaic virus P6 inclusion body formation: a dynamic and intricate process. Virology 553:9-22

Angel CA, Lutz L, Yang XH, Rodriguez A, Adair A, Zhang Y, Leisner SM, Nelson RS, Schoelz JE (2013) The P6 protein of Cauliflower mosaic virus interacts with CHUP1, a plant protein which moves chloroplasts on actin microfilaments. Virology 443:363-374

Athanasiou K, Dyson BC, Webster RE, Johnson GN (2010) Dynamic acclimation of photosynthesis increases plant fitness in changing environments. Plant Physiol 152:366-373 
Baker NR (2008) Chlorophyll fluorescence: a probe of photosynthesis in vivo. Annu Rev Plant Biol 59:89-113

Brickell C (ed) (1994) The Royal horticultural society gardeners' encyclopedia of plants and flowers. Dorling Kindersley, London

Brusse MJ (1965) Glass-house and field observations on Cauliflower and Turnip mosaic viruses in relation to the breeding for virus tolerance. New Zeal J Agric Res 8:672-680

Covey SN, Turner DS (1991) Comparison of viral nucleic acid intermediates at early and late stages of Cauliflower mosaic virus infection suggests a feedback regulatory mechanism. J Gen Virol 72:2603-2606

Fan TT, Ni JJ, Dong WC, An LZ, Xiang Y, Cao SQ (2015) Effect of low temperature on profilins and ADFs transcription and actin cytoskeleton reorganization in Arabidopsis. Biol Plant 59:793-796

Gardner RC, Howarth AJ, Hahn P, Brown-Luedi M, Shepherd RJ, Messing J (1981) The complete nucleotide sequence of an infectious clone of Cauliflower mosaic virus by M13mp7 shotgun sequencing. Nucl Acids Res 9:2871-2888

Haas M, Bureau M, Geldreich A, Yot P, Keller M (2002) Cauliflower mosaic virus: still in the news. Mol Plant Pathol 3:419-429

Harries PA, Palanichelvam K, Yu W, Schoelz JE, Nelson RS (2009) The Cauliflower mosaic virus protein P6 forms motile inclusions that traffic along actin microfilaments and stabilize microtubules. Plant Physiol 149:1005-1016

Hohn T (2013) Plant pararetroviruses: interactions of Cauliflower mosaic virus with plants and insects. Curr Opin Virol 3:629-638

Honjo MN, Emura N, Kawagoe T, Sugisaka J, Kamitani M, Nagano AJ, Kudoh H (2020) Seasonality of interactions between a plant virus and its host during persistent infection in a natural environment. ISME J 14:506-518

Hull R (ed) (2002) Matthews' plant virology, 4th edn. Academic Press, San Diego

Hull R, Covey SN (1985) Cauliflower mosaic virus-pathways of infection. BioEssays 3:160-163

Kassanis B (1957) Effects of changing temperature on plant virus diseases. Adv Virus Res 4:221-241

Leisner SM, Schoelz JE (2018) Joining the crowd: integrating plant virus proteins into the larger world of pathogen effectors. Annu Rev Phytopathol 56:89-110

Leisner SM, Turgeon R, Howell SH (1992) Long distance movement of Cauliflower mosaic virus in infected turnip plants. Mol PlantMicrobe Interact 5:41-47

Liu JZ, Richerson K, Nelson RS (2009) Growth conditions for plant virus-host studies. Curr Prot Microbiol 14:16A. 1.1-161A 1.16
Love AJ, Yun BW, Laval V, Loake GJ, Milner JJ (2005) Cauliflower mosaic virus, a compatible pathogen of Arabidopsis, engages three distinct defense-signaling pathways and activates rapid systemic generation of reactive oxygen species. Plant Physiol 139:935-948

Lutz L, Okenka G, Schoelz J, Leisner S (2015) Mutations within A 35 amino acid region of P6 influence self-association, inclusion body formation, and Caulimovirus infectivity. Virology 476:26-36

Pound GS, Walker JC (1945a) Differentiation of certain crucifer viruses by the use of temperature and host immunity reactions. J Agric Res 71:255-278

Pound GS, Walker JC (1945b) Effect of air temperature on the concentration of certain viruses of cabbage. J Agric Res 71:471-485

Ritchie GA (2006) Chlorophyll fluorescence: what is it and what do the numbers mean? In: Riley LE et al (eds) National proceedings: forest and conservation nursery associations 2005. USDA Forest Service, Rocky Mount Res Stn, Fort Collins, pp 34-42

Sanfaçon H, Wieczorek A (1992) Analysis of Cauliflower mosaic virus RNAs in Brassica species showing a range of susceptibility to infection. Virology 190:30-39

Saunders K, Lucy A, Covey SN (1990) Susceptibility of Brassica species to Cauliflower mosaic virus infection is related to a specific stage in the virus multiplication cycle. J Gen Virol 71:1641-1647

Schoelz JE, Leisner S (2017) Setting up shop: the formation and function of the viral factories of Cauliflower mosaic virus. Front Plant Sci 8:1832

Szittya G, Silhavy D, Molnár A, Havelda Z, Lovas A, Lakatos L, Bánfalvi Z, Burgyán J (2003) Low temperature inhibits RNA silencing-mediated defence by the control of siRNA generation. EMBO J 22:633-640

Torres MA, Ritchie RJ, Lilley RMCC, Grillet C, Larkum AWD (2014) Measurement of photosynthesis and photosynthetic efficiency in two diatoms. New Zeal J Bot 52:6-27

Yamaoka N, Morita T, Furusawa I, Yamamoto M (1982) Effect of temperature on the multiplication of Cauliflower mosaic virus. $\mathrm{J}$ Gen Virol 61:283-287

Young-Mathews A (2012) Plant guide for field mustard (Brassica rapa var. rapa). USDA natural resources conservation service. Corvallis Plant Materials Center, Corvallis

Publisher's Note Springer Nature remains neutral with regard to jurisdictional claims in published maps and institutional affiliations. 